\title{
Pengaruh Faktor Eksposi dengan Ketebalan Objek pada Pemeriksaan Foto Thorax Terhadap Gambaran Radiografi
}

\author{
Ayu Wita Sari ${ }^{1 *}$ dan Enggel Fransiska ${ }^{2}$
}

\section{Intisari}

Telah dilakukan penelitian tentang hubungan faktor exspos dengan ketebalan objek pada pemeriksaan foto thorax terhadap hasil gambaran radiografi menggunakan pesawat sinar-X. Pemberian faktor ekspos yang tidak sesuai dapat menyebabkan radiograf tidak dapat memberikan informasi secara optimal, faktor ekspos yang terlalu tinggi dapat menyebabkan hasil radiografi hitam (gelap) begitu juga pemberian faktor ekspos yang terlalu rendah akan mengakibatkan hasil menjadi putih (terang). Perbedaan pemberian faktor ekspos pada setiap pengambilan foto radiografi dipengaruhi oleh ketebalan yang dimiliki tiap objek. Semakin tebal objek yang akan difoto maka faktor ekspos yang digunakan akan semakin tinggi. Untuk mendapatkan hasil radiografi yang bagus diperlukan faktor ekspos yang tepat sehingga dapat membantu dalam mendiagnosa untuk tahap selanjutnya. Dari hasil pengamatan di lapangan didapatkan nilai untuk faktor eksposipada ketebalan objek $14 \mathrm{~cm}$; kV:47, mAs:7,1, t:35, 16cm; kV:48, mAs:8, t:39, 18cm; kV:49, mAs:9, t:45.

Kata Kunci: Sinar-X, Faktor ekspos, Thorax, Kualitas radiograf

\section{Pendahuluan}

Dalam bidang Medis, penggunaan sinar- $X$ untuk pencitraan diagnostik telah digunakan selama lebih dari satu abad. Penggunaan sinar- $X$ dalam bidang medis, berfungsi memberikan suatu informasi dari tubuh manusia, sehingga dokter dapat melakukan tindakan secara benar sesuai dengan informasi yang didapatkan (Sinaga, 2006).

\footnotetext{
Afiliasi Penulis

1 | STIKes Guna Bangsa Yogyakarta

2 | Universitas Jambi
}

Korespondensi kepada

A.W. Sari

ayu.0221@gmail.com
Teknologi Radiografi telah digunakan di Rumah Sakit kota maupun Rumah Sakit daerah. Teknologi Radiograf yang digunakan yaitu Radiografi konvensional berbasis film. Radiografi konvensional dalam pemanfaatannya menggunakan pesawat Sinar-X dan film untuk mendapatkan hasil gambar yang diinginkan dalam bentuk film Radiograf. Pemeriksaan radiografi yang rutin dilakukan diinstalasi radiologi RSUD Raden Mattaher Jambi meliputi seluruh organ tubuh yaitu, kepala, thorax, abdomen, tulang belakang, ekstrimitas atas dan bawah dan pemeriksaan organ-organ perkencingan.

Namun pada penelitian ini penulis hanya meneliti pada pemeriksaan radiografi thorax karena, pada rongga thorax banyak terdapat organorgan penting seperti, jantung, paru-paru, hati, dan saluran pernafasan. Disamping itu kunjungan pasien pada pemeriksaan thorax di instalasi radiologi ini cukup tinggi yaitu $50 \%$ dari rata-rata 
pasien yang melakukan kunjungan perhari. Oleh karena itu, perlu diketahui faktor ekspos yang ada pada mesin Rontgen, sehingga dalam penggunaannya tidak sembarangan melainkan memiliki parameter yang menghasilkan kualitas Sinar- $X$ yang baik.

Kualitas radiograf adalah kemampuan radiograf dalam memberikan informasi yang jelas mengenai obyek atau organ yang akan diperiksa. Kualitas radiograf ditentukan oleh beberapa komponen antara lain: densitas, kontras, ketajaman dan detail. Faktor eksposi adalah faktor yang mempengaruhi dan menentukan kualitas dan kuantitas dari penyinaran radiasi sinar- $X$ yang diperlukan dalam pembuatan gambar radiograf. Faktor eksposi terdiri dari tegangan tabung (kV), arus tabung (mA), dan waktu ekspos (ms) (Pradana, 2011).

\section{Metode}

Jenis penelitian yang digunakan adalah jenis penelitian kualitatif dengan pendekatan observasi. Pengambilan data pada penelitian ini dilakukan di Instalasi Radiologi RSUD Raden Mattaher Jambi pada bulan Januari - Maret 2017.

\section{Alat Penelitian}

a. Pesawat sinar-X (gambar 1)

\section{Merk : Pesawat Sinar-X Villa Sistem} Medicali S.p.A.

2. $\mathrm{kV} \quad: 42 \mathrm{kV}-55 \mathrm{kV}$

3. $\mathrm{mAs}: 2.8 \mathrm{~mA}-15 \mathrm{~mA}$

4. second : $12 \mathrm{~ms}-72 \mathrm{~ms}$

b. Kaset (Imaging Plate) ukuran $35 \times 35 \mathrm{~cm}$

c. Grid ukuran $35 \times 35 \mathrm{~cm}$

\section{Langkah-Langkah Penelitian}

Metode pengambilan foto rontgen pada thorax, yaitu :

1 Pasien yang akan melakukan foto thorax sebelumnya diperiksa/dibersihkan dari logam atau benda padat lainnya.

2 Pasien berdiri/duduk pada standar yang telah disediakan.

3 Diatur jarak FFD 80-100 cm.

4 Diatur lebar lampu kolimator sesuai dg lebar tubuh pasien.

5. Diukur tebal thorax pasien yang akan difoto.
6. Diatur besar $\mathrm{kV}$ dan $\mathrm{mAs}$ sesuai dengan tebal thorax pasien.

7. Kemudian dieksposi menggunakan Pesawat Sinar-X Villa Sistem Medicali S.p.A.

8. Setelah selesai film diproses/dicuci dikamar gelap.

\section{Hasil \& Pembahasan}

\section{Faktor Exspos}

Faktor ekspos adalah faktor dalam yang mengontrol karakteristik foton sinar- $X$ dalam aspek jumlah (kuantitas) dan (kualitas) serta durasi dalam pembuatan Radiograf. Untuk mengetahui besar Faktor Eksposipada pengambilan foto Rontgen Thorax dengan variasi tebal objek, terlebih dahulu dilakukan pengukuran tebal Thorax yang akan difoto terhadap variasi nilai tegangan tabung (kV) dan nilai arus tetap (mAs). Nilai kondisi Faktor Eksposi ini adalah kondisi pemeriksaan untuk thorax AP (sinar mengarah dari depan ke belakang) ataupun PA (sinar mengarah dari belakang ke depan). Berdasarkan teori KC-Clark, pemilihan Faktor eksposi dengan parameter tebal objek pada pemeriksaan Radiografi Thorax dipilih besarnya tegangan dengan variasi $\pm 6 \mathrm{~cm}$ sampai $\pm 30 \mathrm{~cm}$ yakni dengan variasi (42-55 kV). Dari hasil pengamatan yang dilakukan di lapangan didapatkan hasil hubungan ketebalan objek

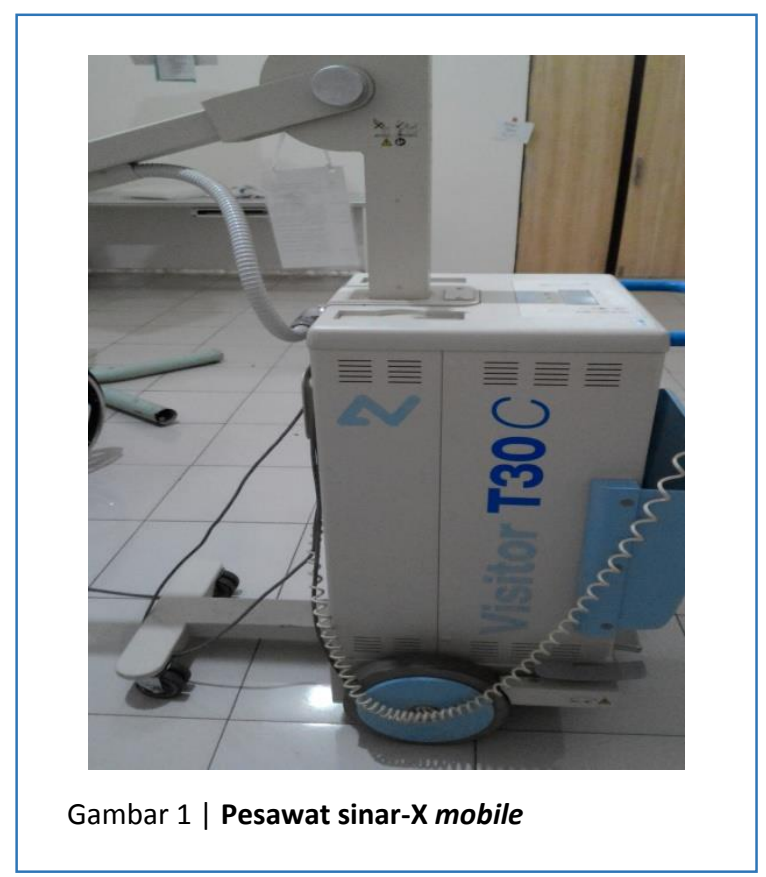


Tabel 1 | Hubungan faktor eksposi dengan ketebalan thorax pada pesawat sinar-X Sistem Medicali S.p.A.

\begin{tabular}{|c|c|c|c|}
\hline \multirow{2}{*}{$\begin{array}{l}\text { Tebal Thorax } \\
\text { (cm) }\end{array}$} & \multicolumn{3}{|c|}{ Faktor Eksposi } \\
\hline & $(\mathrm{kV})$ & (mAs) & (ms) \\
\hline 6 & 42 & 2.8 & 12 \\
\hline 8 & 43 & 4 & 20 \\
\hline 10 & 44 & 5 & 24 \\
\hline 12 & 45 & 6.1 & 31 \\
\hline 14 & 47 & 7.1 & 35 \\
\hline 16 & 48 & 8 & 39 \\
\hline 18 & 49 & 9 & 45 \\
\hline 20 & 50 & 9 & 45 \\
\hline 22 & 50 & 10 & 50 \\
\hline 24 & 51 & 11 & 55 \\
\hline 26 & 52 & 11 & 59 \\
\hline 28 & 53 & 12.5 & 63 \\
\hline 30 & 55 & 15 & 72 \\
\hline
\end{tabular}

(thorax) dengan Faktor Eksposi dapat dilihat pada Tabel 1.

\section{Tegangan Tabung Pesawat Sinar- $X$}

Tegangan tabung dengan satuan kiloVolt (kV) adalah beda potensial antara kutub anoda dan katoda. Tegangan tabung berhubungan dengan kecepatan dan energi kinetik elektron menumbuk bidang target. Nilai $\mathrm{kV}$ atau kualitas Sinar-X berhubungan dengan energi serta daya tembus (penetration power) diukur dari nilai HVL (Half Value Layer) tabung pesawat Sinar-X.

Tegangan tabung berhubungan dengan energi sinar- $X$ yang dihasilkan, semakin besar tegangan maka energi sinar- $X$ yang dihasilkan makin besar serta daya tembusnya juga besar. Pengaturan tegangan tabung pada pembuatan radiograf mengontrol nilai kontras radiograf. Makin tinggi pemilihan nilai tegangan tabung $(\mathrm{kV})$ maka nilai kontras yang dihasilkan makin turun. Faktor yang mempengaruhi adalah efek interaksi Compton yang menghasilkan radiasi hambur (scatter) serta penurunan nilai koefisien attenuasi linier. Efek radiasi hambur ini adalah mengurangi nilai kontras, sehingga semakin tebal objek thorax yang akan difoto maka tegangan tabung yang akan diberikan pada pesawat sinar- $X$ akan bertambah.

\section{Arus tabung pesawat sinar- $X$}

Arus tabung satuannya adalah miliAmper (mA) merupakan besarnya arus listrik antara anoda dan katoda. Arus tabung yang menentukan jumlah atau kuantitas sinar-X yang oleh tabung roentgen. Kuantitas radiasi berhubungan dengan banyaknya jumlah Sinar-X diukur berapa jumlah $m R$ tiap mAsnya. Nilai $m A$ dipilih mengontrol nilai kehitaman film yang dihasilakan agar selalu dalam rentang densitas guna $(0,25-2,0)$. Pemilihan $m A$ juga berhubungan dengan pemilihan ukuran fokal spots, mA besar maka focal spots yang dipilih besar begitu sebaliknya. Dalam praktek $\mathrm{mA}$ dipilih dengan waktu eksposi atau durasi sinar-X terjadi (mAs). Waktu eksposi (s) merupakan satuan detik yanga lamanya berkas sinar- $X$ yang di paparkan pada organ yang di periksa. Waktu penyinaran ini bebeda-beda sesuai dengan objek yang di periksa, misalnya pada organ yang bergerak (jantung, kolon, lambung). Maka waktu penyinaran di buat sesingkat mungkin untuk menghidari terjadinya ketidak tajaman akibat pergerakan (unsharpness movement). Sehingga dari hasil penelitian yang telah dilakukan didapatkan hasil setiap kenaikan ketebalan pada objek thorax nilai mAs akan bertambah maka banyaknya jumlah sinar-x yang dipancarkan juga akan semakin besar.

\section{Jarak penyinaran}

Focus film distance (FFD) merupakan jarak dari sumber sinar (fokus) ke image receptor (film). FFD memberikan pengaruh terhadap intensitas sinar- $X$ dan paparan radiasi yang mencapai permukaan kulit. FFD juga mempengaruhi dosis radiasi yang di terima pasien, semakin dekat FFD dengan objek maka radiasi yang di terima objek semakin banyak. Sedangkan jika FFD semakin jauh maka sedikit radiasi yang mengenai objek.

\section{Teknik Radiografi Thorax}

Teknik pemeriksaan Radiografi Thorax merupakan suatu pemotretan dengan menggunakan tegangan tabung yang cukup tinggi untuk memperlihatkan gambaran organ dan tulang yang ada di dalam thorax. Pemeriksaan Radiografi Thorax dilakukan untuk menilai jantung, paru, mediastinum dan dinding dada. Pemeriksaan radiografi toraks untuk menilai jantung dan paru sangat penting untuk penilaian awal dan 
merupakan pelopor untuk pemeriksaan berikutnya. Menurut K.C. Clark untuk pembuatan Radiografi Thorax di gunakan besar kV yaitu 40-50 $\mathrm{kV}$ dari pembuatan radiografi untuk menilai bentuk organ dan struktur tulang yang ada di sekitarnya.

Pada dasarnya untuk pemotretan Thorax umumnya menggunakan kV yang cukup tinggi, hal ini di sebabkan karena Thorax memiliki jaringan yang cukup tebal sehingga memiliki daya absorbsi yang cukup tinggi terhadap sinar-X. Sehingga apabila menggunakan tegangan tabung (kV) yang rendah dikhawatirkan tidak dapat menembus objek yang akan difoto.

Dari Gambar 2 dapat dilihat hasil hubungan ketebalan objek yang terukur dengan besar pemberian Faktor Eksposi dapat disimpulkan bahwa pada grafik biru yang menunjukkan kV setiap kenaikan ketebalan objek tegangan tabung (kV) yang diberikan akan berangsur meningkat ini disebabkan daya tembus yang diperlukan untuk melewati bahan akan semakin tinggi sehingga sinar $X$ dapat membentuk densitas pada film radiografi. Pemilihan potensial $(\mathrm{kV})$ yang terlalu rendah akan menyebabkan penyinaran yang diberikan tidak mampu menghasilkan densitas pada film. Sedangkan pemilihan potensial (kV) yang terlalu tinggi akan menimbulkan gambar film yang buruk sehingga informasi yang diperlukan hilang (kabur).

Dan pada grafik merah yang menunjukkan kenaikan nilai mAs terhadap kenaikan tebal objek thorax yang terukur dapat dilihat bahwa nilai mAs yang didapat berangsur naik disebabkan perubahan jumlah elektron yang dihasilkan filamen dan intensitas berkas elektron sehingga mempengaruhi intensitas sinar-x yang dikeluarkan karna pengaturan nilai $m A$ yang diatur. Peningkatan $\mathrm{mA}$ akan menambah intensitas sinar$X$, dan penurunan $\mathrm{mA}$ akan mengurangi intensitas. Sehingga semua intensitas sinar- $X$ atau derajat terang (brightness) akan bertambah sesuai dengan peningkatan intensitas radiasi sinar-x di titik fokus Oleh sebab itu, derajat terang dapat diatur dengan mengubah $\mathrm{mA}$.

Grafik hijau menunjukan Waktu penyinaran (ms) digunakan untuk menentukan lamanya penyinaran. Hal ini terutama dimaksudkan untuk mengurangi ketidak tajaman gambar yang dihasilkan di film karena gerakan objek yang diambil. Dengan waktu penyinaran yang minimal dapat digunakan untuk mengontrol densitas ratarata bayangan. Bila waktu penyinaran yang dipilih ditingkatkan atau diperbesar akan mengakibatkan gambar yang dihasilkan di film menjadi kurang tajam. Hal ini terjadi bila ada faktor gerakan dari objek yang diradiasi.

Dari hasil grafik dapat disimpulkan bahwa semakin tebal objek yang akan difoto pemberian nilai $k V$ dan $m A s$ pada pesawat sinar-x akan semakin besar sehingga menyebabkan waktu (ms)

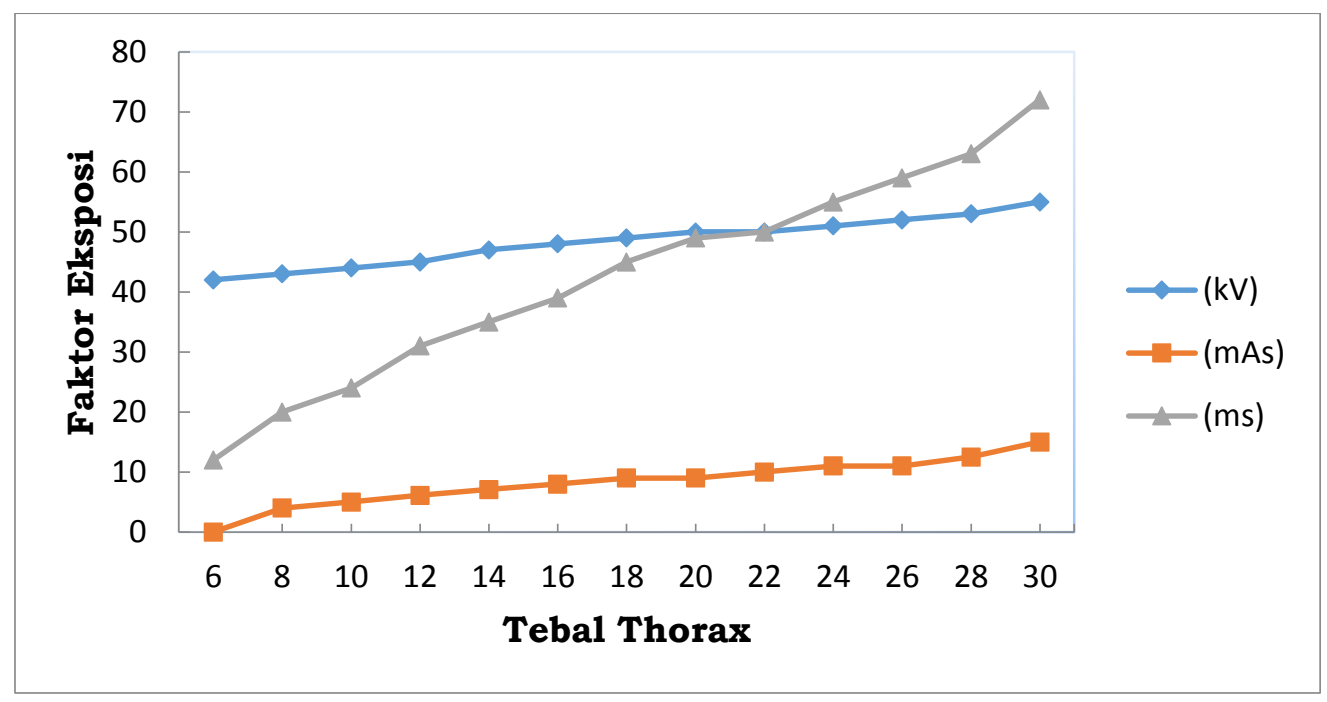

Gambar 2 | Hubungan kenaikan faktor eksposi dengan ketebalan objek thorax 
yang dibutuhkan untuk menembus objek akan semakin lama.

Berdasarkan hasil dan diskusi di atas maka beberapa saran yang ditawarkan ialah sebagai berikut:

1. Sebaiknya dilakukan penelitian dan dibuatkan faktor eksposi untuk pemeriksaan radiografi yang dilakukan atau dilayani di instalasi radiologi RSUD Raden Mattaher Jambi.

2. Mengingat keberadaan dari pesawat Rontgen yang ada begitu banyak dan mempunyai spesifikasi yang berbeda maka sebaiknya Faktor Eksposi hendaknya ditempel pada masing-masing pesawat.

3. Nilai yang didapatkan dari penelitian ini juga dapat dijadikan pemilihan faktor eksposi yang optimal dari pemeriksaan teknik radiografi thorax

\section{Kesimpulan}

1. Hubungan faktor ekspose terhadap ketebalan objek thorax adalah semakin tebal objek yang akan difoto faktor ekspose yang diberikan pada pesawat sinar- $X$ akan semakin besar.

2. Dari hasil penelitian pada pemeriksaan hubungan faktor eksposi dengan ketebalan objek (thorax) diperoleh nilai Faktor Eksposi tertinggi pada ketebalan objek $30 \mathrm{~cm}$ (pada tegangan $55 \mathrm{kV}$, arus $15 \mathrm{mAs}$, waktu $72 \mathrm{~ms}$ )

3. Terendah dengan tebal $6 \mathrm{~cm}$ (pada tegangan $42 \mathrm{kV}$, arus $2.8 \mathrm{mAs}$, waktu $12 \mathrm{~ms}$ ).

\section{Bibliografi}

1. Bontrager Kenneth L, 2000, Textbook of Radiographic Positioning and Anatomy, Sydney Mosby A Harcout Health Sciences Company.

2. Bushberg Jerold, 2001, The Essential Physics of Medical Imaging ,2 th ed, New York. Lippingcotti William \& Wilkins, New York.

3. Bushong,Stewart C. 1988, Radiologic Science For Technologists, fourt edition. C.V. Mosby company. Washington

4. Curry TJ, Dowdey JE, Murry RC, 1990, Crestensen's Physics of Diagnostoc Radiology, 4 th ed, Pheledelphia London, Lea \& Febiger.

5. Chesney, D.N. 1971.Radiographic, Photography, Third Edition, Blackwell Scientific Publications. Oxford, London Edinburgh Melbourne
6. Hoxter E, 1973, Teknik Memotret Rontgen, terjemahan Sombu P., Penerbit Erlangga Jakarta.

7. Imran, Ali. 2015. Pedoman Pengorganisasian Instalasi Radiologi RSUD Raden Mattaher Jambi. FINASIM. Jambi

8. Jenkins, David, 1980, Radiographic Photography and Imaging Processes, An Aspen publications, Aspen publishers, Rockville, Maryland.

9. KC Clark,MBE,FSR. 1973. Positioning In Radiography. London : ILFORD LIMITED.

10. Meridith,WJ, Massey JB, 1977, Fundamental Physics of Radiology , John Wrigh \& Son, Bristol

11. Pradana A. E. D., 2011, Pengukuran Penggunaan kV Pada Pemeriksaan Thorak Anak Terhadap Kualitas Gambar Dan Dosis Radiasi, Universitas Indonesia FMIPA, Jakarta

12. Sinaga, M.S., 2006. Dasar-Dasar IImu Radiologi. Penebar Swadaya. Jakarta

13. Syahrir, dkk, 2001, Radiologi Diagnostik, Jakarta. Bag.Radiologi FKUI 